IRA-International Journal of Education \& Multidisciplinary Studies

ISSN 2455-2526; Vol.04, Issue 01 (2016)

Institute of Research Advances

http://research-advances.org/index.php/IJEMS

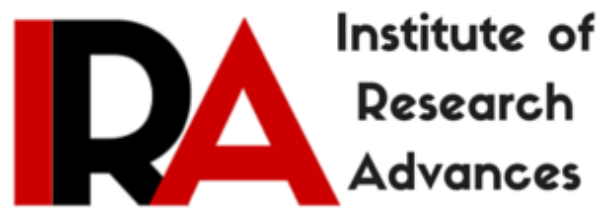

\title{
To Study the Impact of Emotional Intelligence on Academic Achievement of Teacher Trainees
}

\author{
${ }^{1}$ Poonam Sharma \\ Research Scholar \\ Mewar University, India. \\ ${ }^{2}$ Dr. Shubhra Mangal \\ Research Guide \\ Principal \\ Chet Ram College of Education, Noida, India.

\section{${ }^{3}$ Pooja Nagar} \\ M.Ed Student \\ Lingaya's University, India.
}

DOI: http://dx.doi.org/10.21013/jems.v4.n1.p6

\section{How to cite this paper:}

Sharma, P., Mangal, S., \& Nagar, P. (2016). To Study the Impact of Emotional Intelligence on Academic Achievement of Teacher Trainees. IRA International Journal of Education and Multidisciplinary Studies (ISSN 2455-2526), 4(1). doi:http://dx.doi.org/10.21013/jems.v4.n1.p6

(C) Institute of Research Advances

(cc) Br-nc

This works is licensed under a Creative Commons Attribution-Non Commercial 4.0 International License subject to proper citation to the publication source of the work.

Disclaimer: The scholarly papers as reviewed and published by the Institute of Research Advances (IRA) are the views and opinions of their respective authors and are not the views or opinions of the IRA. The IRA disclaims of any harm or loss caused due to the published content to any party. 


\section{ABSTRACT}

\section{"All learning has an emotional base"-Plato}

The present study was conducted to study the impact of Non cognitive factor i.e Emotional Intelligence on the academic achievement of teacher trainees. The study was conducted on 100 graduate teacher trainees pursuing B.Ed. from Lingaya's University. The participants consisted of male and female students in which strength of female was more than male. Average age of all participants was 24 years. Randomization method was used for selection for the participants. Emotional intelligence inventory designed by DR. S.K. Mangal (Guest faculty, Department of Education, M.D. University, Rohtak) and Ms. Shubhra Mangal (Principal C.R.S. College of Education, Noida) was used for the measurement of emotional intelligence of teacher trainees' which consists four areas of Emotional Intelligence i.e Intrapersonal Awareness, Inter-personal Awareness, Intra-personal Management, Inter- personal Management respectively. The result of study reveals that there is positive and significant correlation between Emotional Intelligence and Academic Achievement of teacher trainees.

Key Words: Emotional Intelligence,Teacher Trainees and Academic Achievement

\section{INTRODUCTION:}

Today, students have been living in an age of complex pressure, stress, strain and violence. Disorderly behavior is generally found in most of the schools. This kind of behavior emanates from a number of circumstantial factors .It is because required social skill are neither taught nor practiced in schools. We all have different personalities, different wants and needs, and different ways of showing our emotions. Navigating through this all takes tact and cleverness - especially if we hope to succeed in life. This is where emotional intelligence becomes important. The ability to express and control our own emotions is important, but so our ability to understand, interpret, and respond to the emotions of others. Imagine a world where you couldn't understand when a friend was feeling sad or when a co-worker was angry. Psychologists refer to this ability as emotional intelligence, and some other experts suggested that it is more important than IQ.

Emotional intelligence consists of two words E.I. (Emotion and Intelligence).Emotion refers to "intense feeling of human", Intelligence is basically "based on mental ability of human to deal effectively with the environment".

Emotional intelligence is the ability to sense and understand one's own emotions, to express and regulate then appropriately and to use them in the process of decision making. It includes the capacity to understand and feel for others, and so set up maintain quality relationships.

Emotional intelligence refers to the ability to perceive, control and evaluate emotions. Some researchers suggest that emotional intelligence can be learned and strengthened, while others claim it an inborn characteristic.

Emotional intelligence is the ability to recognize your emotions, understand what they are telling you, and realize how your emotions affect people around you. Emotional intelligence also involves your perception of others: when you understand how they feel, this allows you to manage relationships more effectively.

People with high emotional intelligence are usually successful in the most things they do. Because they're the ones that other's want. They makes other feel good, they go through life much more easily than people who are easily angered or upset.

We probably know people who are academically brilliant and yet are socially inept and unsuccessful at work or in their personal relationships. Intellectual intelligence isn't enough on its own to be successful in their life. IQ can help you to get into college, but it's your EQ that will help you manage the stress and emotions when facing your final exams. 


\section{EMOTIONAL INTELLIGENCE:}

Emotional intelligence is a new concept by Dr. John mayor and Dr.PeterSalovey (1990) from American University. However, it was popularized by American Psychologist Daniel Goleman (1995). Peter Salovey and John D. Mayor have been the leading researchers on emotional intelligence. In their influential article "Emotional Intelligence" they defined emotional intelligence as, "the subset of emotional intelligence that's involves the ability to monitor's one's and other's feelings and emotions, to discriminate among them and to use this information to guide one's thinking and actions" (1990).

Basically the truth is that IQ can help the people successful to the extent of $20 \%$ only in life. The rest of $80 \%$ success depends on EQ.

("The Indian perspective")

\section{THE FOUR BRANCHES OF EMOTIONAL INTELLIGENCE:}

Dr. Salovey and Dr. Mayer proposed a model that identified four different factors of emotional intelligence: the perception of emotion, the ability reason using emotions, the ability to understand emotion and the ability to manage emotions.

1. Perceiving Emotions: The first step in understanding emotions is to accurately perceive them. In many cases, this might involve understanding nonverbal signals such as body language and facial expressions.

2. Reasoning with Emotions: The next step involves using emotions to promote thinking and cognitive activity. Emotions help prioritize what we pay attention and react to; we respond emotionally to things that garner our attention.

3. Understanding Emotions: The emotions that we perceive can carry a wide variety of meanings. If someone is expressing angry emotions, the observer must interpret the cause of their anger and what it might mean. For example, if your boss is acting angry, it might mean that he is dissatisfied with your work; or it could be because he got a speeding ticket on his way to work that morning or that he's been fighting with his wife.

4. Managing Emotions: The ability to manage emotions effectively is a key part of emotional intelligence. Regulating emotions, responding appropriately and responding to the emotions of others are all important aspect of emotional management.

\section{GOLEMAN FIVE COMPONENTS OF EMOTIONAL INTELLIGENCE:}

Goleman broadened Dr.Mayer'sandDr.Salovey's four-branch system to incorporate five essential elements of emotional intelligence. Daniel Goleman developed a framework of five elements that define emotional intelligence:

1 Emotional self-awareness - knowing what one is feeling at any given time and understanding the impact those moods have on others. People with high emotional intelligence are usually very selfaware. They understand their emotions and because of this, they don't let their feelings rule them. They are confident- because they trust their intuition and don't let their emotions get out of control. They are also willing to take an honest look at themselves. They know their strength and weakness. Many people believe that this self-awareness is the most important part of emotional intelligence.

2 Self-regulation - Controlling or redirecting one's emotions; anticipating consequences before acting on impulse. People who self-regulate typically don't allow themselves to become too angry or jealous, and they don't make impulsive, Careless decisions. They think before they act. Characteristics of self-regulation are thoughtfulness, comfort with change, integrity and the ability to say no.

3. Motivation -utilizing emotional factors to achieve goals, enjoys the learning process and perseveres in the face of obstacles. People with a high degree of emotional intelligence are usually motivated. They are highly productive, love a challenge, and are very effective in whatever they do.

4. Empathy - sensing the emotions of others. This is perhaps the second most important element of emotional-intelligence. Empathy is the ability to identify with and understand the wants, needs and viewpoints of those around you. People with empathy are good at recognizing the feelings of others, 
even when those feelings may not be obvious. As a result, empathetic people are usually excellent at managing relationships, listening, and relating to others. They avoid stereotyping and judging too quickly and they live their lives in a very open, honest way.

5. Social skills - managing relationships, inspiring others and inducing desired responses from them. It's usually easy to talk to and like people with good social skills, another sing of high emotional intelligence. Those with strong social skill are typically team players. Rather than focus on their own success first, they help others develop and shine. They can manage disputes, are excellent communicators, and are masters at building and maintaining relationships.

\section{ROLE OF EMOTIONAL INTELLIGENCE IN OUR LIFE:}

Emotional intelligence plays an important role in our life. Emotional intelligence is basically the combination of the feelings / emotions of the head and heart. Emotional intelligence can be a key to success in your personal and carrier life.

\section{EMOTIONAL INTELLIGENCE EFFECTS:}

\section{Performance at work:}

Emotional intelligence can help you navigate the social complexities of the workplace, lead and motivate others, and excel in your career. In fact, when it comes to gauging job candidates, many companies now view emotional intelligence as being as important as technical ability and require EQ testing before hiring.

\section{Physical health:}

If you're unable to manage your stress levels, it can lead to serious health problems. Uncontrolled stress can raise blood pressure, suppress the immune system, increase the risk of heart attack and stroke, contribute to infertility, and speed up the aging process. The first step to improving emotional intelligence is to learn how to relieve stress.

\section{Mental health:}

Uncontrolled stress can also impact your mental health, making you vulnerable to anxiety and depression. If you are unable to understand and manage your emotions, you'll also be open to mood swings, while an inability to form strong relationships can leave you feeling lonely and isolated.

\section{Relationships:}

By understanding your emotions and how to control them, you're better able to express how you feel and understand how others are feeling. This allows you to communicate more effectively and forge stronger relationships, both at work and in your personal life.

\section{HIGH AND LOW EMOTIONAL INTELLIGENCE:}

In this world there are two kinds of people with low emotional intelligence and with high emotional intelligence. They are having different attitude and behaviour to each other.

People with low emotional intelligence are usually very aggressive by nature, face difficulty to adjust with other, poor listener, they easily distracted, had low confidence etc.

People with high emotional intelligence are having strong will power, soft $\mathrm{n}$ polite by nature, patient, good listener etc.

\section{HOW TO IMPROVE EMOTIONAL INTELLIGENCE:}

Emotional intelligence can be learned and developed. As well as working on your skills in the five areas of (Self-awareness, Self - Regulation, Motivation, Empathy, and Social Skills), use these strategies:

\section{Observe how you react to people:}

Do you rush to judgement before you know all of the facts? Do you stereotype? Look honestly at how you think and interact with other people, Try to put yourself in their place, and be more open and accepting of their perspectives and needs. 


\section{Look at your work environment:}

Do you seek attention for your accomplishments? Humility can be a wonderful quality, and it doesn't mean that you are shy or lack self-confidence. When you practice humility, you say that you know what you did, and you can be quietly confident about it. Gives others chance to shine- put the focus on them, and don't worry too much about getting praise for yourself.

\section{Do a self-evaluation:}

What are your weaknesses? Are you willing to accept that you are not perfect and that you could work on some areas to make yourself a better person? Have the courage to look at yourself honestlyit can change your life.

\section{Examine how you react to stressful situations:}

Do you become upset every time there is a delay or something does not happen the way you want?

Do you blame others or become angry at them, even when it's not their fault? The ability to stay calm and in control in different situations is highly valued-in the business world and outside it. Keep your emotions under control when things go wrong.

\section{Take responsibility for your actions:}

If you hurt someone's feelings, apologize directly-don't ignore what you did or avoid the person. People are usually more willing to forgive and forget if you make an honest attempt to make things right.

\section{Examine how your actions will affect others:}

If your decision will impact others, put yourself in their place. How will they feel if you do this? Would you want that experience? If you must take the action, how can you help others deal with the effects?

\section{MEANING OF ACADEMIC ACHIEVEMENT:}

Academic achievement or (academic) performance is the outcome of education - the extent to which a student, teacher or institution has achieved their educational goals. Academic achievement is commonly measured by examinations or continuous assessment. Individual differences in academic performance have been linked to differences in intelligence and personality.Students with higher mental ability as demonstrated by IQ tests and those who are higher in conscientiousness (linked to effort and achievement -motivation) tend to achieve highly in academic settings. A recent metaanalysis suggested that mental curiosity (as measured by typical intellectual engagement) has an important influence on academic achievement in addition to intelligence and conscientiousness. Academic achievement is a multidimensional activity and not a unidimensional one. It generally refers to levels of success of the proficiency in academic work. It indicates what a pupil has learnt or acquired in particular subjects.

\section{STATEMENT OF THE PROBLEM:}

"TO STUDY THE IMPACT OF EMOTIONAL INTELLIGENCE ON ACADEMIC ACHIEVEMENT OF TEACHER TRAINEES."

\section{OBJECTIVES OF THE STUDY}

The following objectives are formulated for the present study:

- To study and measure the Emotional Intelligence of teachers trainees.

- To study the relationship between emotional intelligence and academic achievement of teachers trainees.

- To study the relationship between the Intra-Personal Awareness and Emotional Intelligence of teacher trainees.

- To study the relationship between the Inter- Personal Awareness and Emotional Intelligence of teacher trainees.

- To study the relationship between the Intra- Personal Management and Emotional Intelligence of teacher trainees. 
- To study the relationship between the Inter -Personal Management and Emotional Intelligence of teacher trainees.

\section{HYPOTHESIS:}

On the bases of objectives following hypothesis is formulated for the present study:

- There is a positive and significant relationship between emotional intelligence and academic success of teacher trainees.

- There is a positive and significant relationship between the area of Intra- Personal Awareness and academic achievement of teacher trainees.

- There is a positive and significant relationship between the area of Inter- Personal Awareness and academic achievement of teacher trainees.

- There is a positive and significant relationship between the area of Intra- Personal Management and academic achievement of teacher trainees.

- There is a positive and significant relationship between the area of Inter- Personal management and academic achievement of teacher trainees.

\section{RATIONALE OF THE STUDY:}

For developing, productive and healthy student, a balance has to be struck between the cognitive and emotional domains of learning. Once the Emotional Intelligence skills are developed, strengthened, and enhanced, the student in all likelihood may acquire increased level of personal academic, and carrier achievement. But our students are educated with one main objective in mind: Success in examination or academic achievement. Countless researchers have dwelt on the various factors. Which underline high academic achievement.In the past there have been several attempts to find a substantial relationship between academic achievement and the factors, which contribute toward it, like personality traits, social and environmental factors. The above mentioned markedly showed that emotional and social factor are linked with academic achievement. These factors encompass the individuals intra-personal and interpersonal behaviour, her adaptability with the changing environmental demands, stress management abilities etc. Subsequently, the researcher and Psychologist grouped these factors together and with this emerge a new term, which is called Emotional Intelligence. Major work has been done in this area; still limited studies exist in the Indian setting. The present study attempts to examine the relationship between emotional intelligence and academic achievement in an Indian academic scenario mainly for the teacher trainees.

The major problem facing teacher education is the absence of non-traditional variable of intelligence in the selection process and student retention strategies. Teacher education institutions traditionally use intellectual variables in assessing the teacher trainees in admission process. This remaining in vague despite the research suggesting the non traditional variable of intelligence as being the better predictors of academic achievement than traditional traditional intellectual variables (vela 2003). Higher education institutions many therefore consider emotional intelligence skill as non-traditional variables of intelligence to assist in the admission process and retention interventions. The purpose of the study was to examine the relationship between emotional intelligence skills and academic achievement of teacher trainees. Findings of the study may assist educators in developing a better understanding of the effects of emotional intelligence on the academic achievement.

\section{DELIMITATION:}

Problem is also delimited, which is briefly described as under:

- This study was delimited to B.Ed. teacher trainees only.

- The present study was restricted to 100 teacher trainees.

- The present study was confined to School of Education Lingaya'sUniversity, Faridabad. 


\section{METHODOLOGY USED IN THE STUDY}

The overall plan of the study has been suitably articulated in this chapter under the following heads:

- Selection of problems

- Formulation of the hypothesis

- Objectives of the study

- Delimitation of the study

- Research methods

- Sampling:

a). Population

b). Sample.

- Selection of the tools

- Scoring procedure

- Statistical techniques used.

- Data analysis

- Formulation of Result

VARIABLES USED IN THE STUDY:

Emotional intelligence: Independent variable

Academic Achievement : Dependent variable.

\section{POPULATION}

A population refers to any collection of specified group of human beings or of non-human being. In the present study the population is B.Ed. teacher trainees.

\section{SAMPLE}

100 graduates teacher trainees batch of 2014-2015 pursuing B.Ed. from Lingaya's University consisted of the sample. The participants consisted of male and female students in which strength of female was more than male. Average age of all participants was 24 years. Randomization method was used for selection for the participants.

\section{TOOL:}

ACADEMIC ACHIEVEMENT- Academic Achievement was measured by the marks secured in last semester of B.Ed. The total Marks obtained by the students in the annual examination was noted down from the official records of School of Education .

\section{DATA COLLECTION:}

Emotional intelligence inventory designed by DR. S.K. Mangal (Guest faculty, Department of Education, M.D. University, Rohtak) and Ms. Shubhra Mangal (Principal C.R.S. College of Education, Noida ) was used for the measurement of emotional intelligence of teacher trainees' which consists four areas of Emotional Intelligence i.e Intra-personal Awareness, Inter-personal Awareness, Intra-personal Management, Inter- personal Management respectively.

The investigator herself collected the data for the present study by visiting to Lingaya's University, Faridabad . Investigator also collected the results of end semester of the same sample for the measurement of Academic Achievement.

\section{SCORING PROCEDURE:}

The respondents are requested to indicate or tick mark against any response on one of their choices. Mode of response to each of the item of the inventory is in the form of a forced choice i.e. either Yes or No, indicating complete agreement or disagreement with the proposed statement respectively. In the present Emotional intelligence inventory thus there are item where the response 'Yes' is indicative of the presence of Emotional Intelligence and 'No' for the lack of Emotional Intelligence. Similarly, there are 
items where 'No' response provides clue for the presence of emotional intelligence and 'Yes' for its absence.

STATISTICAL TECHINIQUES USED:

1.MEAN

2.STANDARD DEVIATION

3.KARL PEARSON's COEFFICIENT CORRELATION METHOD

\section{ANALYSIS OF DATA}

The data in the present study was collected with help of Emotional intelligence inventorydesigned by DR. S.K. MANGALand the Academic achievement of B.Ed. teacher trainees.The data was analyzed with the help of mean, standard deviation, karlpearson product moment correlation as to find out the answer of the hypothesis that there is a significant relationship between Emotional Intelligence and Academic Achievement.

The analysis and interpretation of the data obtained with the help of tool in the lighting of objectives given below:

HYPOTHESIS 1:There is a positive and significant relationship between Emotional Intelligence and Academic Achievement of teacher trainees.

\section{TABLE:4.01}

Showing analysis of correlation between Emotional Intelligence and Academic Achievement of teacher trainees.

\begin{tabular}{|c|c|c|c|c|c|}
\hline \multirow{2}{*}{ S.NO } & \multirow{2}{*}{ VARIABLE } & \multirow{2}{*}{ MEAN } & \multirow{2}{*}{ S.D } & \multicolumn{2}{|c|}{ LEVEL OF SIGNIFICANCE } \\
\hline & & & & r value & Table value \\
\hline 1 & $\begin{array}{l}\text { EMOTIONAL } \\
\text { INTELLIGENCE }\end{array}$ & 72.46 & 9.68 & \multirow[t]{2}{*}{0.715} & \multirow{2}{*}{$\begin{array}{l}.195(0.5 \text { level }) \\
.254(.01 \text { level })\end{array}$} \\
\hline 2 & $\begin{array}{l}\text { ACADEMIC } \\
\text { ACHIEVEMENT }\end{array}$ & 507.04 & 53.02 & & \\
\hline
\end{tabular}

INTERPRETATION-Observation of table 4.01 shows that the obtained $r$ value 0.715 between Emotional Intelligence and academic Achievement of teacher trainees is founded higher than the table value (.195and .254) that is significant at .05 and .01 of confidence respectively. This allows us to accept the hypothesis. This reveals that Emotional Intelligence is positively and highly correlated to Academic Achievement of Teacher Trainees.

HYPOTHESIS 2:There is a positive and significant relationship between the Intra- Personal Awareness and Academic Achievement.

TABLE 4.02

Showing analysis of correlation between Intra - Personal Awareness and Academic Achievement.

\begin{tabular}{|c|c|c|c|c|}
\hline \multirow{2}{*}{ VARIABLE } & \multirow{2}{*}{ MEAN } & \multirow{2}{*}{ S.D } & \multicolumn{2}{|c|}{ LEVEL OF SIGNIFICANCE } \\
\hline & & & r value & Tablevalue \\
\hline $\begin{array}{l}\text { Intra - Personal } \\
\text { Awareness }\end{array}$ & 18.11 & 3.72 & .460 & $\begin{array}{l}.195(0.5 \text { level }) \\
.254(.01 \text { level })\end{array}$ \\
\hline
\end{tabular}


INTERPRETATION: Observation of table 4.02 shows that the obtained r value .460 between Intra Personal Awareness and Academic Achievement of Teacher Trainees is found higher than the table value (.195 and .254)that is significant at .05 and .01 of confidence respectively. This allows us to accept the hypothesis. This reveals that Emotional Intelligence is positively and highly correlated to Academic Achievement of Teacher Trainees.

HYPOTHESIS 3:There is a positive and significant relationship between the Inter- Personal Awareness and Academic Achievement.

TABLE 4.03

Showing analysis of correlation between Inter - Personal Awareness and Academic Achievement.

\begin{tabular}{|l|l|l|l|l|}
\hline \multirow{2}{*}{ VARIABLE } & \multirow{2}{*}{ MEAN } & \multirow{2}{*}{ S.D } & \multicolumn{2}{|c|}{ LEVEL OF SIGNIFICANCE } \\
\cline { 4 - 5 } & & r value & Tablevalue \\
\hline $\begin{array}{l}\text { Inter - Personal } \\
\text { Awareness }\end{array}$ & $\mathbf{1 7 . 6 6}$ & $\mathbf{3 . 4 8}$ & $\mathbf{. 4 8 0}$ & $\begin{array}{l}\mathbf{. 1 9 5 ( 0 . 5} \text { level) } \\
\mathbf{. 2 5 4 ( . 0 1} \text { level) }\end{array}$ \\
\hline
\end{tabular}

INTERPRETATION:Observation of table 4.03 shows that the obtained $r$ value .480 between Inter Personal Awareness and Academic Achievement of Teacher Trainees is found higher than the table value (.195 and .254) that is significant at .05 and .01 of confidence respectively. This allows us to accept the hypothesis. This reveals that Emotional Intelligence is positively and highly correlated to Academic Achievement of Teacher Trainees.

HYPOTHESIS 4: There is a positive and significant relationship between the Intra- Personal Management and Academic Achievement.

TABLE 4.04

Showing analysis of correlation between Intra - Personal Management and Academic Achievement.

\begin{tabular}{|c|c|c|c|c|}
\hline \multirow{2}{*}{ VARIABLE } & \multirow{2}{*}{ MEAN } & \multirow{2}{*}{ S.D } & \multicolumn{2}{|c|}{ LEVEL OF SIGNIFICANCE } \\
\hline & & & r value & Tablevalue \\
\hline $\begin{array}{l}\text { Intra - Personal } \\
\text { Management }\end{array}$ & 18.62 & 3.81 & .393 & $\begin{array}{l}.195(0.5 \text { level }) \\
.254(.01 \text { level })\end{array}$ \\
\hline
\end{tabular}

INTERPRETATION: Observation of table 4.04shows that the obtained $\mathrm{r}$ value .393 between Inter Personal Management and Academic Achievement of Teacher Trainees is found higher than the table value (.195 and .254) that is significant at .05 and .01 of confidence respectively. This allows us to accept the hypothesis. This reveals that Emotional Intelligence is positively and highly correlated to Academic Achievement of Teacher Trainees.

HYPOTHESIS 5: There is a positive and significant relationship between the Inter- Personal Management and Academic Achievement.

TABLE 4.05

Showing analysis of correlation between Inter - Personal Management and Academic Achievement.

\begin{tabular}{|l|l|l|l|l|}
\hline \multirow{2}{*}{ VARIABLE } & \multirow{2}{*}{ MEAN } & S.D & \multicolumn{2}{|l|}{ LEVEL OF SIGNIFICANCE } \\
\cline { 4 - 5 } $\begin{array}{l}\text { Inter - Personal } \\
\text { Management }\end{array}$ & $\mathbf{1 8 . 0 8}$ & 4.34 & r value & Tablevalue \\
\hline
\end{tabular}


INTERPRETATION: Observation of table 4.05 shows that the obtained $r$ value .472 between Inter Personal management and Academic Achievement of Teacher Trainees is found higher than the table value (.195 and .254) that is significant at .05 and .01 of confidence respectively. This allows us to accept the hypothesis. This reveals that Emotional Intelligence is positively and highly correlated to Academic Achievement of Teacher Trainees.

\section{SUGGESTIONS FOR FUTURE STUDY}

- Similar study could be done at large scale

- There could be comparative study between Emotional Intelligence and Academic Achievement.

- Future research revel that Emotional Intelligence could be the predictor of Academic Achievement

- Future research should strive to find a specific Emotional Intelligence construct that successfully predict job performance.

- Similar study could find out the effect of Emotional Intelligence of girls and boys at secondary level.

- This study use self-reported GPA as the major of Academic Achievement which was highly correlated with the actual GPA. But longitudinal data could be used for analysis of academic performance.

\section{IMPLICATIONS OF THE STUDY FOR THE STUDENTS:}

- Students should be able to recognize their abilities and capacities instead of feeling low, develop ability to work and study in adverse emotional condition of life.

- It can help future teacher to well equipped with handling new aims, objectives of education, method techniques and ready to take the responsibility which is a tactful task.

\section{FOR THE TEACHERS:}

- The teacher should be competent to identify the changing emotional classroom environment and have the ability to empathize, encourage and connect with student on emotional level.

\section{FOR THE INSTITUTIONS:}

- Education institution should consider on adding practical courses that help student function at a higher level of emotional level which would improve their performance at work place.

- A specific emotional intelligence course could include interaction and actual practice in some of the areas related to emotional intelligence.

- There should be an arrangement in school to help students who are suffering from some emotional problem.

- In curriculum impetus should be given for the training of emotional intelligence to increase academic achievement of students.

\section{CONCLUSION:}

To sum up, it can be stated that the outcome of all five hypothesis is accepted.It is true that there is positive and significant correlation between Emotional Intelligence and Academic Achievement. There is a great need to explore the awareness about the Emotional Intelligence. Emotional Intelligent people are more likely to succeed in everything they undertake. Quality emotions and feeling help student give their best potential in the classroom. The students who are aversive and think negatively cannot concentrate for a long time and have more difficulty in reaching their potential than others. The emotions, feelings, and values are vital for a person well being and achievement in life. 


\section{BIBLIOGRAPHY}

- Abraham, R. (1999) Emotional intelligence in Organization: A conceptualization Genetic, Social and General Psychology Manographs, 125,209-224.

- Abraham, R. (2005) Emotional Intelligence in Work place: A review and synthesis. In R. Schulze and R.D. Robers (Eds.) Emotional Intelligence :

- An international Handbook (pp. 225) Cambridge, Mass: Hogrefe and Huber Publisher.

- Alex, M., and Ajawani J.C. (2008) Syllogistic reasoning problem solving ability as a function of emotional intelligence. Paper Presented at National Seminar on 'Psychology for better Life'. (12th\& 13thSeptember 2008) Arts and commerce Girls college Raipur (C.G.)

- Athota, V.S. O' Connor, P.J. and Jackson (2009). The role of emotional intelligence and personality in moral reasoning sciences Book Chapter, (Research on line.nd.edu.au/sci_chapters/1)

- Austin E., Evans, P., Magnus, B. and O’ Hanlon, K. (2007) A preliminary study of empathy, Emotional intelligence and examination performance in MB Ch B students. Medical Education, 41,7, 684-689.

- Austin, E.J. (2004). An investigation of the relationship between trait emotional intelligence and emotional task performance 36,8, 1855-1864. (Psy.abs.2004, 919, 3265)

- Austin, E.J., Saklofske, D.H. and Egan, V. (2005). Personality, well-being and health correlates of trait emotional intelligence. Personality and Individual differences, 38, 3, 547-558 (Psy. abs. 2005, 92,5, 1623)

- Bansal, A.K. (2007) How EQ and SQ affects the science achievement of the secondary level students. Indian Journal of Psychometry and Education, 38,1,92-93

- Barbera. K.L. Charoenchote, W., In, S., and Barchard, K.A. (2003) Relating emotional and Social Intelligence to sex and Age. Poster presented at the Nevada State Psychological Association annual meeting, Las Vegas, N V. May, 17.

- Barchard, K.A. (2003) Does emotional intelligence assist in the prediction of academic success? Educational and Psychological measurement, 63, 5, 840-858.

- Bar-on, R (2002). The Emotional Intelligence Inventory: Short (EQ-I -S) :Technical

- Bar-on, R(2005). The Bar-on model of emotional- social intelligence. In P.Fernandez- Berrocal and N. Extremera (Guest Editore), Speical Issue on Emotional Intelligence.Psicothema, 17.

- Bastia, V.A. Nicholas, R.Burns, and Nettelbeck, T. (2005). Emotional Intelligence Predicts life skills, but not as personality and cogniveability. Personality and Individual Differences, Retrieved July 5, 2005, from :www.sciendirect.

- Bay, Sussana.G.K.and Lim, K.M. (2006). Correlations of multiple intelligence and emotional intelligence: A closer Analysis of theoretical assumptions. Korean Journal of thinking and problem solving, 16,1,53-64 (Psy abs. 93,7, 2393)

- Bernstein, D.A., Roy. E.J., Srull, T.K., and Wickens, C.D.(2003) Convergent, discriminant, and incremental validity of competing measures of emotional intelligence. Personality and social Psychology Bulletin, 29,1147-1158

- Bhattacharya, M., Dutta, A.K., and Mandal M.K. (2004) .factor structure of emotional Intelligence in India, Psychological studies, 49, 142-146

- Bhosle,S.(1999)GenderdifferencesinEQ.In:http://www.megafoundation.rog/ultralhiq.hiqnews/gen erdifferences.

- Bindu, p, and Thomas, I. (2006) Gender Differences in Emotional Intelligence Psychological studies, 51,4,261-268

- Cameron, A. (1999) Worman Profile questionnaire emotional intelligence (WPQei) Test agency Ltd. Cray: House Oxon. RG94AE.

- Carbonneau, D. and Nicol, A.M. (2002). Emotional Intelligence andprosocial Behavior in Adolescent: Psychological reports, 90, 361-370. 
- Carr, S.E. (2009). Emotional intelligence in medical Student: Does it correlate with selection measures? Medical Education, 43, 11, 1069-1077.

- Davies, M., Stankav, L., and Roberts, R.D. (1998) Emotional Intelligence: in search of an elusive construct. Journal of personality and social psychology, 75, 989-1015.

- Dawda, D. and Hart, S.D. (2000) Assessing emotional intelligence: reliability of the Bar-on Emotional Quotient Inventory. Journal of personality and individual Differences, 28, 797-812.

- Dey, N. (2009) Influence on emotional intelligence on academic self-efficacy and achievement. Psycho-lingua, 39,2, 171-174.

- Engelberg, E. and Sjoberg, J (2004). Emotional Intelligence, affect intensity, and social adjustment. Personality and Individual Differences, 37, 3, 533,-542 (Psy.abs.2004, 91, 11, 4043)

- Eniola, M.S. (2007). The Influence of emotional intelligence and self-regulation strategies on remediation of aggressive behaviours in adolescent with visuasl impairment Ethno-med, 1, 1, 7177.

- Extremera, N. and Fernandez- Berrocal, P (2005) Perceived emotional intelligence and life satisfaction: predictive and incremental validity using the trait Meta-mood Scale. Personality and Individual differences, 39,5,937-948 (Psy. abs. 2006,93,1,7)

- Fischer, A.H. and Manstead, A. R. (2000). The relationship between gender and emotions in different cultures. pp. 71-94: A. H. Fischer (ed.): Gender and Emotion: Social Psychological Perspective. Cambridge University Press.

- Fisher, C.D. (2000) Moodd and emotion while working: missing pieces of job satisfaction? Journal of organizational behaviour, 21, 185-202.

- Jain, A.K. and Sinha, A.K. (2005), General health in organizations: relative Relevance of emotional intelligence, Trust and organizational support.International Journal of stress Management 12,3, 257-273 (Psy. abs. 2005, 92,12, 4438-4437)

- K. Gowdhaman, K. and M. BalaMurugan, (2009) Emotional Intelligence among the B.Ed teacher Trainees. Psycho-lingua, 39,2,187-190.

- Saranya, R. and Velayudharn, A(2008) Analysingprosocial behavior and emotional intelligence among university students. Psycho-lingua, 38(2),126-132

- Tapia, M.L. (1999). A study of the relationship of the emotional intelligence inventory (intelligence tests) Dissertation Abstract International.

- Tatwawadi, S (2009) Emotional maturity of management student. Psycho-lingua, 39,1,78-82

- Tapia, M.L. (1999). A study of the relationship of the emotional intelligence inventory (intelligence tests) Dissertation Abstract International.

- Tatwawadi, S (2009) Emotional maturity of management student. Psycho-lingua, 39,1,78-82

- Van Rooy, D.L., Viswesvaran, C. and Pluta, P. (2005). An Evaluation of construct validity: What is this thing called emotional Intelligence? Human Performance 18,4, 445-462 (Psy abs. 2005, 92,12, 4235-4236)

- Zeidener, M., Shani-Zinovich, J., Ma tthews, G., and Roberts, R.D. (2005) Assessing emotional intelligence in gifted and non-gifted school students: outcomes depend on the measure. Intelligence, 33, 4, 369-399

- Zizzi, S.J. Deaner, H.R. and Hirschhorn, D.K. (2003). The relationshipbetween emotional intelligence and performance among college baseball players. Journal of Applied sport Psychology, 15,3,262-269.(Psy.abs.2003, 90,12, 4263)

\section{- WEB REFERENCES:}

- www.dipscom.info/adolescents

- www.eiconsortium.org/reports/emotional_competenceframework.html

- www.who.int/topics/child_adolescent-health 